TAPROBANICA, ISSN 1800-427X. April, 2012. Vol. 04, No. 01: pp. 57-58.

(C) Taprobanica Private Limited, Jl. Kuricang 18 Gd.9 No.47, Ciputat 15412, Tangerang, Indonesia.

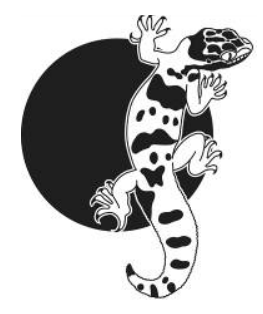

\section{The advertisement call of Kandyan shrub frog (Pseudophilautus rus)}

The Kandyan Shrub Frog, Pseudophilautus rus (Manamendra-Arachchi \& Pethiyagoda, 2005) (Fig. 1 ) is known only from two localities around Kandy (500-800 m a.s.l), Sri Lanka; Kiribathkumbura and Pilimatalawa. Mature males attain a SVL of 20.6$24.1 \mathrm{~mm}$ and mature females up to $23.1 \mathrm{~mm}$ (Manamendra-Arachchi \& Pethiyagoda, 2005). $P$. rus perches on low vegetation, usually on leaves and branches of shrubs, grass, and logs, 0.1-1.5 m above the ground. Males of the species produce one of the most frequently heard calls in suburban and urban areas in Kandy, together with the common shrub frog $P$. popularis. Here, I describe for the first time the advertisement call of $P$. rus.

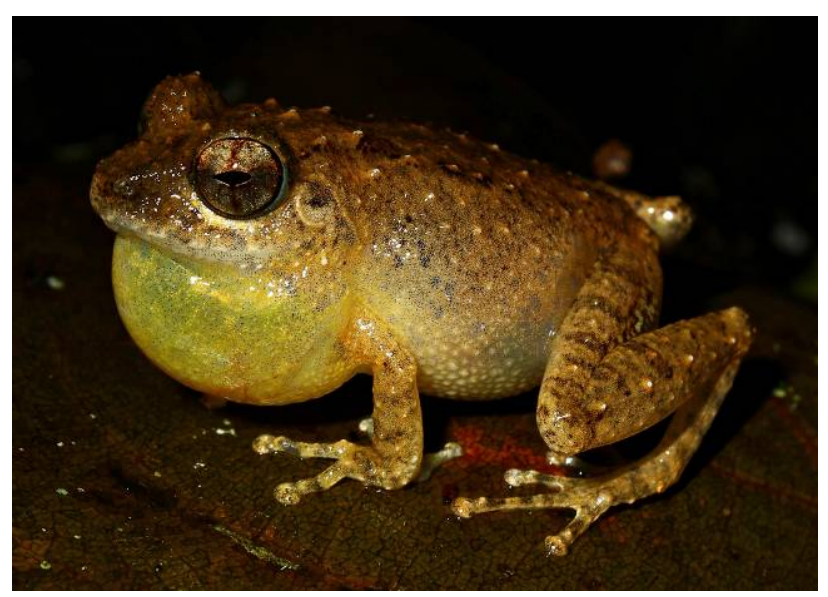

Figure 1: Pseudophilautus rus in Nawalapitiya

The vocalizations of P.rus were studied under natural conditions in two locations in the Kandy district; Peradeniya ( $7^{\circ} 15^{\prime} 29.00^{\prime}$ N, 80 36' 01.00” E; alt. $504 \mathrm{~m}$ a.s.l) and Nawalapitiya (7० 02' 42.01” N, 80 32' 15.43” E; alt. $630 \mathrm{~m}$ a.s.l). Advertisement calls were recorded during the months of June and July 2011, using Creative ZEN $^{\circledR}$ Mozaic EZ (wave format). Advertisement calls were recorded from animals vocalizing alone to avoid alteration of advertisement calls (Bee \& Bowling, 2002), and recordings were made at a distance of $0.5 \mathrm{~m}$. Animals were not captured for measurements to avoid disturbance as the frogs were also part of a behavioural study. Ambient temperature was measured using a Brannon mercury thermometer $\left(-20-100{ }^{\circ} \mathrm{C}, \pm 0.5{ }^{\circ} \mathrm{C}\right)$. Recordings were made at $25-28{ }^{\circ} \mathrm{C}$ air temperature. The following software was used for sound analysis: Windows movie maker (Vista), Syrinx 1.0.0.1 and Wavesurfer 1.8.8. All calls were edited with a sampling rate of $44.1 \mathrm{kHz}$ and 16 bits per sample in the mono pattern. The audio spectrogram was constructed using Wavesurfer 1.8.8 software with Fast Fourier Transformation: width 512 points, bandwidth of $86.132 \mathrm{~Hz}$ using Blackman window. A total of 77 calls produced by seven males (9-11 calls per individual) were included in the analysis. Temporal and Spectral parameters were analyzed as explained in Samarasinghe (2011). The temporal parameters measured were duration of one call (DC) and intercall interval (IC). The number of prominent pulses in a note (NP) and the pulse rate (PR) were also recorded. The spectral parameters measured were lower frequency (F1), upper frequency (F2) and peak frequency (F3). Numerical call parameters are given as range followed by mean + SD in parenthesis.

Pseudophilautus rus was found to begin vocalizing around 18:00 $\mathrm{h}$ and end around 06:30 h. In Peradeniya, this species was found perched on low vegetation, usually on the leaves and branches of shrubs, grass, and logs, at 0.1-1.5 $\mathrm{m}$ above the ground. In Nawalapitiya, $P$. rus was found in sympatry mainly with $P$. folicola and $P$. popularis. In Nawalapitiya, $P$. rus was found calling from microhabitats such as dry leaves of ferns, deep crevices of short tree trunks and short shrubs found on either side of foot paths $0.3-2 \mathrm{~m}$ above ground level. The advertisement call was the most common call emitted by $P$. rus, consisted of a short, multipulsed note. This note is amplitude modulated, with amplitude decreasing over time. The DC ranged between 27-36 ms (31.78 $\pm 1.178 \mathrm{~ms}, \mathrm{n}=77)$, and the IC was 4.29-10.36 s (6.02 $\pm 1.428 \mathrm{~s}, \mathrm{n}=39)$. Each call consisted of $4-10(6.31 \pm 1.18, n=77)$ prominent pulses and the pulse rate ranged from 129.03-312.50 s $\mathrm{s}^{-1}\left(198.37 \pm 34.56 \mathrm{~s}^{-1}, \mathrm{n}=77\right)$. F1 
ranged from $1.6-2.0 \mathrm{kHz}(\mathrm{n}=77)$, $\mathrm{F} 2$ ranged between $3.3-3.8 \mathrm{kHz}(\mathrm{n}=77)$ and F3 was $2.4-3.2$ $\mathrm{kHz}(\mathrm{n}=77)$.
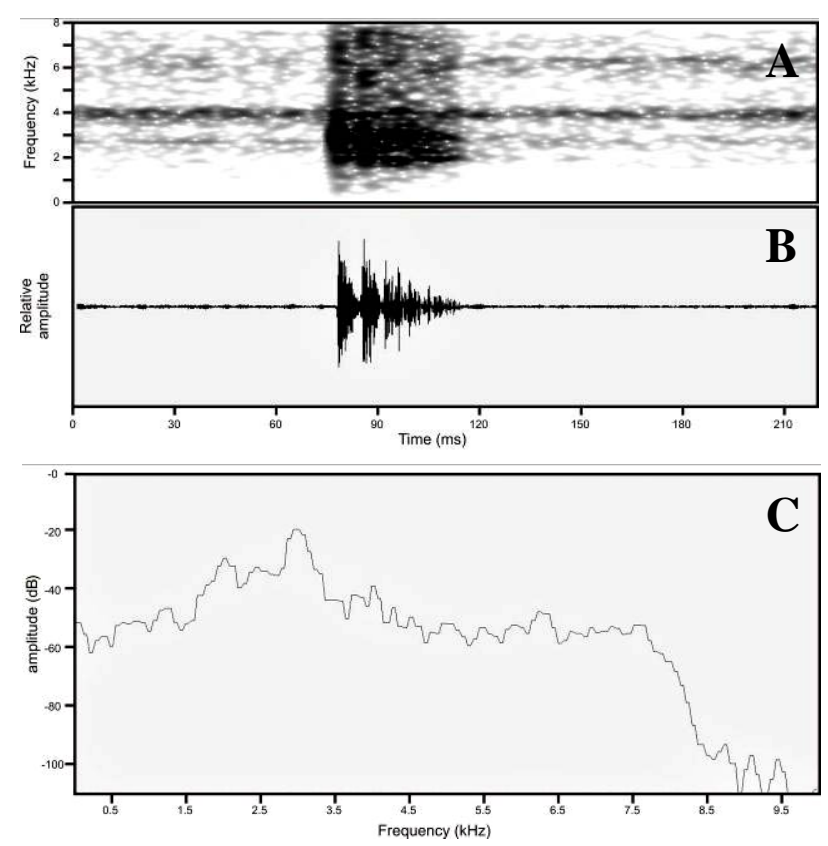

Figure 2: (A) spectrogram, (B) waveform, and (C) power spectrum of the advertisement call of Pseudophilautus rus, recorded at $25.5^{\circ} \mathrm{C}$.

\section{Acknowledgements}

I am very grateful for Imesh Nuwan Bandara (YES) and Dushantha Kandambi for their support given in the field and for providing hospitality during the field visits. My gratitude also goes for Mahesh Chathuranga for his help with graphics.

\section{Literature Cited:}

Bee, M. A. and A. C., Bowling, 2002. Sociallymediated pitch alteration by territorial male bullfrogs, Rana catesbeiana. Journal of Herpetology, 36, 140143.

Manamendra-Arachchi, K. and R. Pethiyagoda, 2005. The Sri Lankan shrub frogs of the genus Philautus Gistel, 1848 (Ranidae: Rhacophorinae), with description of 27 new species. In: Yeo, C. J., Ng, P. K. L. \& Pethiyagoda, R. (Eds.), Contributions to biodiversity exploration and research in Sri Lanka. The Raffles Bulletin of Zoology, Supplement 12, 163303.

Samarasinghe, D. J. S., 2011. Description of the complex advertisement call of Pseudophilautus popularis (Manamendra-Arachchi \& Pethiyagoda, 2005) (Amphibia: Rhacophoridae). Zootaxa, 3002, 62-64.
Submitted: 09 May 2012, Accepted: 15 May 2012 Sectional Editor: Jodi Rowley

Dinal J. S. Samarasinghe

The Young Zoologists’ Association of Sri Lanka, National Zoological Gardens, Dehiwala, Sri Lanka E-mail:dinal.salvator@gmail.com 